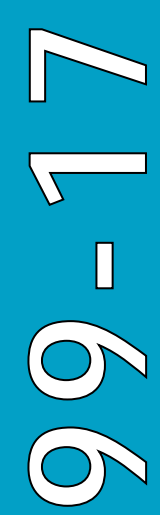

Expedient Low-Temperature Conc rete Admixtures for the Army

CharlesJ. Korhonen November 1999 
Abstract: Over 50 chemical combinations were studied for their effect on the strength gain of mortar when it is below freezing. The chemicals studied were limited to those that are readily available most anywhere, but that are not marketed as admixtures for concrete. Four admixtures were developed from these chemicals that allowed mortar to gain full strength at $-10^{\circ} \mathrm{C}$ as rapidly as normal mortar cured at temperatures between 5 and $10^{\circ} \mathrm{C}$. A host of other chemicals allowed mortar to recover full strength when cooled to the point that cement hydration ceased or that allowed mortar to continually gain modest strength while at low temperature with only minimal loss of ultimate strength. Guidance is provided for expedient field use- for concrete not expected to last more than 5 years.

How to get copies of CRREL technical publications:

Department of Defense personnel and contractors may order reports through the Defense Technical Information Center: DTIC-BR SUITE 0944

8725 J OHN J KINGMAN RD

FT BELVOIR VA 22060-6218

Telephone 18002253842

E-mail help@dtic.mil

msorders@dtic.mil

WWW http://www.dtic.mil/

All others may order reports through the National Technical Information Service:

NTIS

5285 PORT ROYAL RD

SPRINGFIELD VA 22161

Telephone 17034874650

17034874639 (TDD for the hearing-impaired)

E-mail orders@ntis.fedworld.gov

WWW http://www.ntis.gov/index.html

A complete list of all CRREL technical publications is available from

USACRREL (CEERD-IM-HL)

72 LYME RD

HANOVER NH 03755-1290

Telephone 16036464338

E-mail_techpubs@crrel.usace.army.mil

For information on all aspects of the Cold Regions Research and Engineering Laboratory, visit our World Wide Web site:

http://www.crrel.usace.army.mil 


\section{Special Report 99-17}

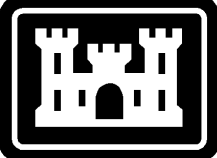

US Army Corps

of Engineers $\otimes$

Cold Regions Research \&

Engineering Laboratory

\section{Expedient Low-Temperature \\ Conc rete Admixtures for the Army}

Charles J . Korhonen

November 1999 


\section{PREFACE}

This report was prepared by Charles J. Korhonen, Research Civil Engineer, Civil Engineering Research Division, Cold Regions Research and Engineering Laboratory, U.S. Army Engineer Research and Development Center.

The investigation was funded by DA Project 4A762784AT42, Military Engineering Technology, Cold Regions Theater of Operations; Work Package 162; Work Unit AT42-TO-011, Expedient Cold-Weather Concrete Admixtures. Technical review of this report was provided by Deborah Loiselle, Research Supervisor, New Hampshire Department of Transportation, and Dr. Asok Sarkar, Research Engineer, The University of Dayton, Dayton, Ohio. The author acknowledges the diligent work of Sherri Orchino, Civil Engineering Technician, CRREL, for her laboratory expertise in conducting these tests.

The contents of this report are not to be used for advertising or promotional purposes. Citation of brand names does not constitute an official endorsement or approval of the use of such commercial products. 


\section{CONTENTS}

Preface

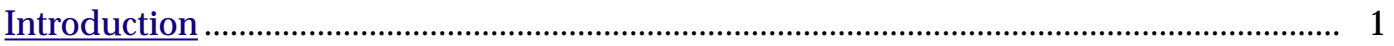

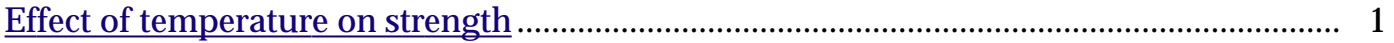

Test program

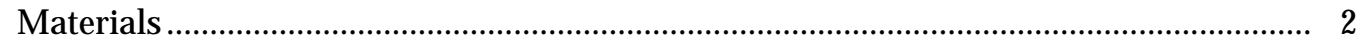

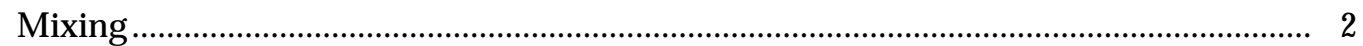

Sample preparation and curing ............................................................................. 2

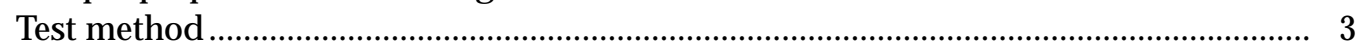

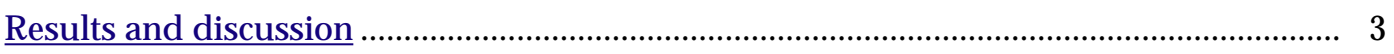

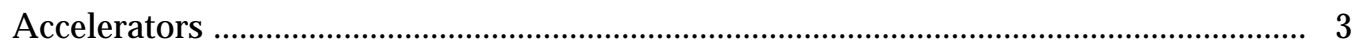

Freezing point depressants ..................................................................................... 4

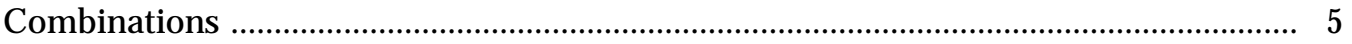

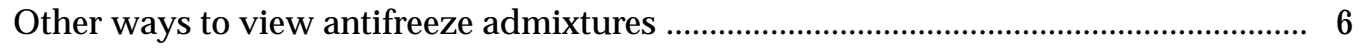

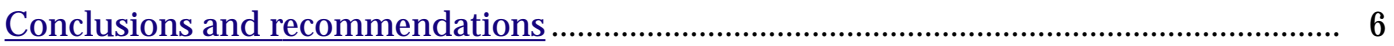

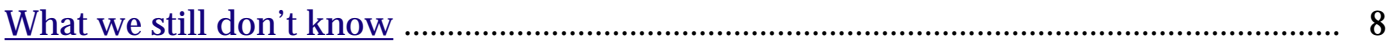

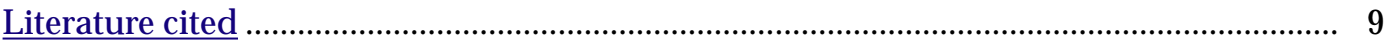

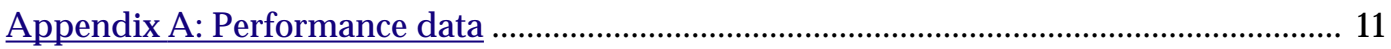

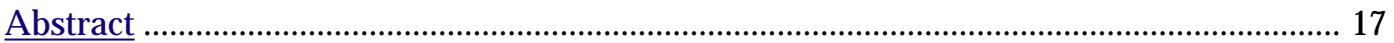

\section{ILLUSTRATIONS}

Figure

1. Relationship between chemical dosage and freezing point ...................................... 4

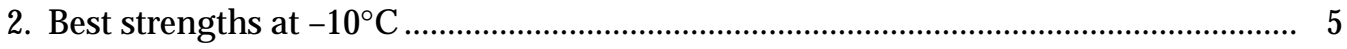

\section{TABLES}

Table

1. Effect of temperature on strength gain of control mortar ........................................ 2

2. Early age strength from the best accelerators ............................................................ 3

3. Mortars that recovered more than $95 \%$ strength after being cured at $-20^{\circ} \mathrm{C}$ for 28 days and then at $20^{\circ} \mathrm{C}$ for an additional 28 days ............................................. 6

4. Admixtures that will produce strength at $-10^{\circ} \mathrm{C}$ at least as fast as normal concrete

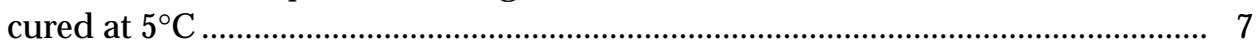

5. Everyday chemicals that allow concrete to gain at least $75 \%$ strength after being at low temperature for 28 days followed by room temperature for 28 days ....... 7 



\title{
Expedient Low-Temperature Concrete Admixtures for the Army
}

\author{
CHARLES J. KORHONEN
}

\section{INTRODUCTION}

Currently, portland cement concrete cannot be placed at below-freezing temperatures without some form of thermal protection. Therefore, Field Manual, FM 5-428, Concrete and Masonry (U.S. Army 1998), directs that freshly placed concrete must be protected from freezing by keeping it above $5^{\circ} \mathrm{C}$ with insulation or heated enclosures for a minimum of 3 days or until it has sufficiently cured to gain strength and serve its intended purpose. On the battlefield or in an emergency, when concrete must be placed regardless of the temperature, engineers may not have access to insulation, let alone heated enclosures. If concrete must be placed in the cold, it may freeze and the results can be disastrous.

An alternate approach to winter concreting, and one not yet recognized by standard practice, is to use antifreeze admixtures. These are chemicals that depress the freezing point of water and accelerate the hydration rate of cement when the internal temperature of the concrete is below $0^{\circ} \mathrm{C}$. Commercial standards do not permit the use of antifreeze admixtures because their long-term effect on concrete is unknown. However, two recently completed studies (Korhonen and Brook 1996, Korhonen et al. 1997b) concluded that certain chemicals could protect concrete from freezing without causing detrimental side effects. But, partly out of resistance to change and partly for other reasons, antifreeze admixtures have not been commercialized and are not in general use.

This report details a laboratory investigation in search of chemicals to allow portland cement concrete to resist freezing during initial curing. This search targeted chemicals, other than those specifically marketed for concrete, for their effect on early age strength gain. It did not consider their effect on paste shrinkage, aggregate degradation, reinforcing steel corrosion, or concrete durability. (These studies should be conducted if the concrete is intended for long-term use.) The objective of this study was to develop guidance to enable military engineers to design expedient cold weather concrete admixtures, from chemicals that are readily available but not marketed expressly as concrete admixtures, for field expedient use. Expedient concrete is defined as concrete that is intended to have service life up to 5 years.

\section{EFFECT OF TEMPERATURE ON STRENGTH}

Portland cement concrete, in its simplest form, is composed of cement, aggregate, and water. A chemical reaction between the cement and water forms a gel that binds the aggregate together and gives concrete its strength. As long as the cement is wet, the concrete continues to gain strength at a rate that is strongly influenced by temperature.

Common belief is that hot weather is the best time to cast concrete because concrete sets up faster when it is hot than when it is cold. Table 1 supports this belief by showing that mortar gains $77 \%$ more strength in 1 day when cured at $50^{\circ} \mathrm{C}$ than it does when cured at $20^{\circ} \mathrm{C}$. Getting this much extra strength in 1 day can save an engineer several days of extra expense in labor and in waiting time to reuse the forms. However, the strength benefits are only temporary. As can be seen, the early age strength increase caused by high temperatures virtually disappears by day 7 . Moreover, the mortar ultimately becomes $28 \%$ weaker when cured at $50^{\circ} \mathrm{C}$ than when cured at 
Table 1. Effect of temperature on strength gain* of control (admixture-free) mortar.

\begin{tabular}{ccccccc} 
Temp & \multicolumn{7}{c}{ Strengt $^{+}$} \\
\cline { 2 - 7 }$\left({ }^{\circ} \mathrm{C}\right)$ & 1 day & 3 days & 7 days & 14 days & 28 days & 56 days \\
\hline 50 & 17.7 & 33.6 & 58.1 & 69.3 & 75 & 77 \\
40 & 16 & 38.1 & 69.7 & 79.2 & 85 & 85 \\
30 & 13.1 & 36.6 & 72.1 & 87.3 & 94 & 93 \\
20 & 10 & 30 & 70 & 90 & 100 & 105 \\
10 & 3.7 & 15 & 49 & 75.6 & 97 & 110 \\
5 & 2 & 14 & 30.1 & 56.7 & 83 & 100 \\
-5 & 1 & 6.7 & 14 & 16.6 & 20.3 & 46.8 \\
-10 & 0 & 0.2 & 1.7 & 2.7 & 4.2 & 51.1 \\
-20 & 0 & 0 & 0 & 0.2 & 0.8 & 37.3 \\
\hline
\end{tabular}

* The strengths for $20,-5,-10$, and $-20^{\circ} \mathrm{C}$ are results produced at CRREL on $0.39 \mathrm{w} / \mathrm{c}$ mortar. The others are expected strengths according to ACI (1988).

+ Strengths are given as percentages of the 28-day strength of control mortar cured at $20^{\circ} \mathrm{C}$. The mortars were cured at the temperature shown in the left most column for 28 days, then they were cured at $20^{\circ} \mathrm{C}$ for the remaining 28 days.

$20^{\circ} \mathrm{C}$. Thus, hot weather might allow the project to go faster but it can result in permanent strength loss.

In the long run, concrete becomes stronger when cured at temperatures that are low but above freezing. Their drawback is that they slow down strength gain, which can adversely affect construction schedules. If concrete can be mixed and protected so that its temperature can be kept at $5^{\circ} \mathrm{C}$, preferably at $10^{\circ} \mathrm{C}$, strength gain can be rapid enough to avoid too much delay. Table 1 shows that mortar cured at $10^{\circ} \mathrm{C}$ develops 63 and $50 \%$ less strength compared to mortar cured at $20^{\circ} \mathrm{C}$ for 1 and 3 days, respectively. By 56 days, this strength deficit turns into a strength surplus of nearly $5 \%$. Compared to $50^{\circ} \mathrm{C}$, it becomes a $33 \%$ strength surplus. Curing at $5^{\circ} \mathrm{C}$ produces similar results. Thus, cold weather can be the best time to cast concrete.

However, too much cold leads to problems. If concrete freezes at an early age, it can be permanently damaged. As Table 1 shows, the 1-day strength of $-5^{\circ} \mathrm{C}$ mortar is only $10 \%$ that of mortar cured at $20^{\circ} \mathrm{C}$; no appreciable strength developed at -10 or $-20^{\circ} \mathrm{C}$. Though hydration occurs at temperatures as low as $-20^{\circ} \mathrm{C}$, albeit slowly, less than half of the concrete's strength can be recovered by thawing. Thus, cold weather protection is required to achieve strong concrete when the temperature dips below $0^{\circ} \mathrm{C}$.

\section{TEST PROGRAM}

The test program defined the effects of various chemicals, singly and in combination, on the freezing point depression of mix water and the strength gain of mortar as a function of time and temperature.

\section{Materials}

This study used mortar as a rapid way to evaluate various chemicals. Mortar, instead of concrete, simplified mixing operations, reduced material handling, and permitted smaller test specimens, which meant less material had to be taken to the landfill. In addition, mortar closely simulates concrete because it has the same paste to aggregate transition zones, except that the aggregate is smaller. The mortar was non-airentrained, ${ }^{*}$ used Type I portland cement at a 1:2.75 ratio with sand, and was made with waterto-cement $(\mathrm{w} / \mathrm{c})$ ratios between 0.39 and 0.45 (the majority of the testing was at $0.41 \mathrm{w} / \mathrm{c}$ ). The sand, sieved for use in concrete, had a bulk specific gravity (saturated surface-dry) of 2.65 and a moisture absorption of $1.1 \%$. The mixing water was from the taps at CRREL.

\section{Mixing}

Mixing of the mortar followed standard laboratory procedures. The mortars were mixed in a Hobart mixer according to ASTM (1987) Standard C305 with minor modifications. The chemical additives were dissolved in the mixing water before the entire solution was placed into a damp mixing bowl. The mixer was turned on at low speed for 30 seconds while the cement was added. The mixer was stopped, the sides of the bowl were scraped down, and mixing was resumed for 45 seconds while the sand was added. The mixer was briefly stopped, changed to medium speed, and run for 30 seconds. Then, the mixer was stopped for $1 \frac{1}{2}$ minutes before finally being run at medium speed for 1 minute.

\section{Sample preparation and curing}

The mortar was mixed at room temperature. Immediately after mixing it was cast into $50.8-\times$ 101.6-mm plastic cylindrical molds, vibrated on a table to ensure consolidation, capped with plastic lids, and stored at $20,-5,-10$, and $-20^{\circ} \mathrm{C}$ (some mixes were not stored at $-20^{\circ} \mathrm{C}$ to simplify testing). The samples were placed into their respective curing rooms within 30 minutes after water

\footnotetext{
* Non-air-entrained mortar was used intentionally to determine the effect additives have on strength development without having to contend with the variability of entrained air. Entrained air is recommended for field applications.
} 
first came in contact with the cement. They remained sealed until being tested for strength.

\section{Test method}

Three samples of each mix from each temperature were tested in uniaxial compression according to ASTM (1997) Standard C39 at 7, 14, 28, and 56 days (some samples were not tested at 14 or 56 days owing to scheduling problems). Each sample was capped with unbonded neoprene held within a steel-retaining cup according to ASTM (1993) Standard C1231. The samples from the coldrooms were allowed to thaw to $5^{\circ} \mathrm{C}$ before being tested.

\section{RESULTS AND DISCUSSION}

Appendix A shows freezing point and strength data for over 50 chemicals. Although many more could have been studied, I focused on a small portion of chemicals known to be compatible with concrete. They are grouped into Tables A1 through A4 by their ability to accelerate the strength gain of mortar, by their ability to depress the freezing point of mixing water, by those that are liquid, and by those that were combined together. Rather than discuss each table in detail, I summarized them into the tables and graphs that follow and referenced them, as necessary, in the text below. The reader is encouraged to review Appendix A for additional detail.

In reading this report, it is important to note that all strengths are referenced to the 28-day strength of control mortar cured at $20^{\circ} \mathrm{C}$. Table 1 was organized in this manner. Likewise, Appendix A lists all strengths as percentages.

\section{Accelerators}

One function of an antifreeze admixture is to accelerate the hydration rate of portland cement. Any increase in the early strength development shortens the curing and protection periods necessary for the concrete to attain the desired strengths. Table A1 highlights chemicals that force mortar to gain strength faster than it normally would. Table 2, extracted from Table A1, shows the best results.

It is clear that the seven chemicals shown in Table 2 increased the early strengths of mortar. They produced 7-day strengths at $20^{\circ} \mathrm{C}$ that many times exceeded that of control mortar. In fact, compared to Table 1, they all far outperformed

Table 2. Early age strength from the best accelerators from Appen$\operatorname{dix}$ A.

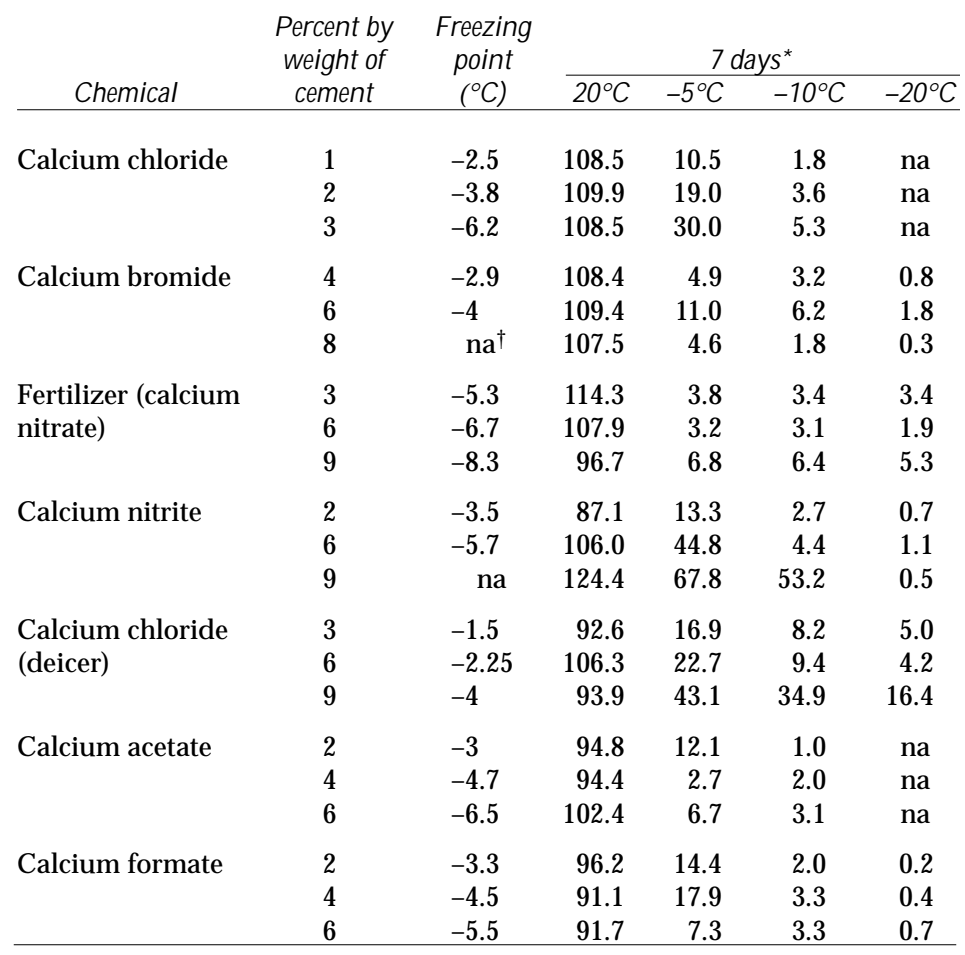

* Strengths are given as percents of 28-day control mortar cured at $20^{\circ} \mathrm{C}$.

${ }^{\dagger}$ Tests were not conducted, or information was not available. 
the control mortar at $50^{\circ} \mathrm{C}$. Except for calcium chloride and calcium bromide, the amount of strength increase depended on the amount of chemical added to the mortar. The calcium chloride and calcium bromide produced approximately the same 7-day strengths despite differences in doses.

The best known cement hydration accelerator is calcium chloride. As Table 2 shows, it provides more strength gain at a given dosage than the other accelerators. It is also the cheapest of all the chemicals tested in this study. However, a major drawback of calcium chloride is its tendency to corrode metal. As a result, calcium chloride is not recommended by current standards beyond $2 \%$ by weight of cement in reinforced concrete and is not recommended at all in pre-stressed concrete. But, for expedient purposes where long-term effects are less important or for non-reinforced structures where corrosion is not an issue, higher dosages are acceptable. Up to $4 \%$ was included in this study. For practical purposes, the amount of accelerator that can be added to concrete is limited by how early the concrete stiffens before interfering with placing, consolidating, and finishing operations. Since ready-mix concrete is often produced at temperatures around $20^{\circ} \mathrm{C}$ during the winter, the accelerating potential of chemicals was judged at this temperature. Based on this study, the optimum dosage of accelerators appears to be between 4 and $8 \%$ for concrete cured at $20^{\circ} \mathrm{C}$.

At lower temperatures, accelerator dosages can be higher. Calcium chloride and calcium nitrite were the most active chemicals studied. They produced 7 -day strengths at $-10^{\circ} \mathrm{C}$ that were comparable to control mortar cured between 5 and $10^{\circ} \mathrm{C}$. Since accelerators are only one component of an antifreeze admixture, these results are remarkable. Interestingly, too, the lowest measured freezing points of the mix waters were -6.2 and $-5.7^{\circ} \mathrm{C}$ for the calcium chloride and calcium nitrite, respectively. These are not insignificant from practical considerations as the control mortar froze at $-1.3^{\circ} \mathrm{C}$.

\section{Freezing point depressants}

The second and final function of an antifreeze admixture is to depress the freezing point of water. This function depends on a colligative property called molality-the number of particles (moles) that dissolve into $1 \mathrm{~kg}$ of water. This is a group of chemicals that are generally weak accelerators or retarders, and includes both electrolytes and nonelectrolytes. Electrolytes are materials that dissociate into more than 1 mole of ions per formula weight, whereas nonelectrolytes remain in molecular form. Examples of electrolytes are sodium chloride and sodium acetate and of nonelectrolytes are alcohols and glycols. They work on the principle that solute particles lower the vapor pressure and, thus, the freezing point of water.

Figure 1, developed from Appendix A data, shows that, generally, the greater the number of solute particles, the lower the freezing point. This relation is independent of the type of chemical used, provided the chemical remains soluble at

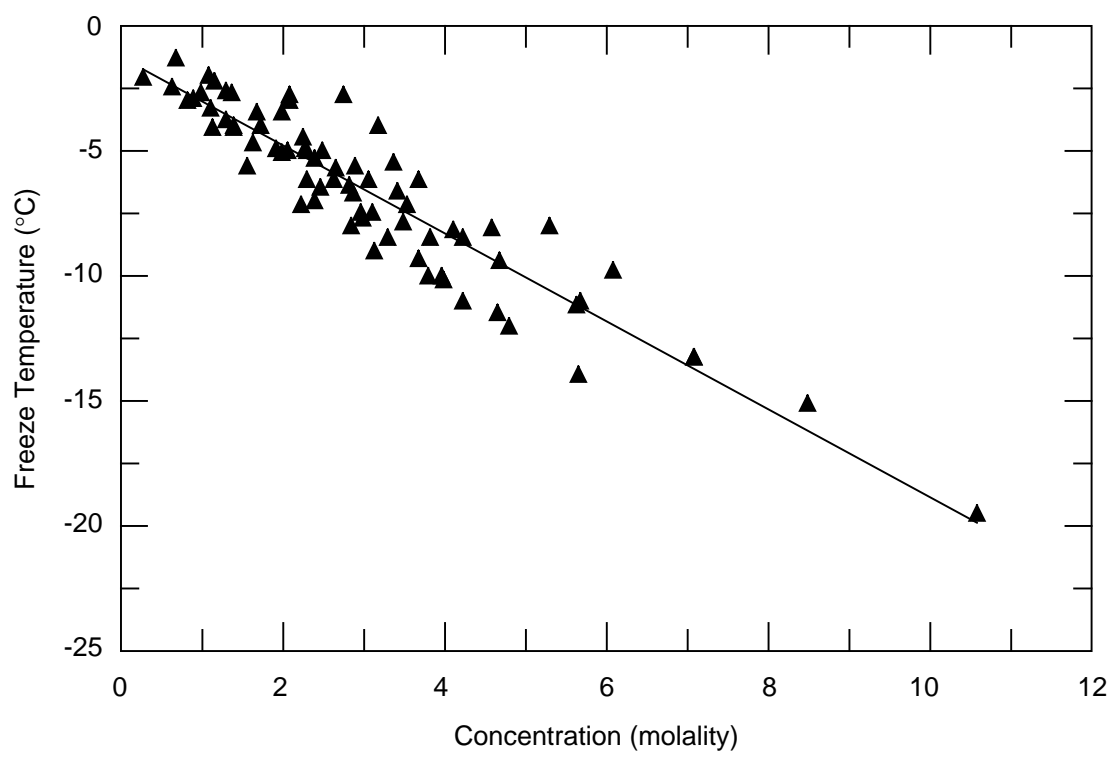

Figure 1. Relationship between chemical dosage and freezing point. 
low temperatures. As seen, there is a scattering of the data points about the least-squares regression line drawn through them. This scattering is probably caused by variations in attractive forces between particles and in solubility from chemical to chemical. The least-squares line reveals that each mole (mol) of solute reduces the freezing point $(F P)$ of the water by $1.76^{\circ} \mathrm{C}$. Further, it shows that admixture-free mortar should freeze at $-1.28^{\circ} \mathrm{C}$. (The measured freezing point of the control mortar was $-1.3^{\circ} \mathrm{C}$.)

$$
F P=-1.76 \mathrm{~mol}-1.28 \text {. }
$$

Interestingly, the relationship between molality and freezing point remains quite good, even at the highest dosage. Thus, eq 1 is a good first estimate of expected freezing point whenever the chemical composition of the admixture is known. However, it is always best to experimentally determine the freezing point because, as noted, the colligative behavior of chemicals can vary from that predicted by eq 1 .

\section{Combinations}

The basic antifreeze admixture utilizes both accelerators and freezing point depressants. Other chemicals, such as plasticizers, retarders, and air entrainers, can be used, but this study did not evaluate them. My objective was to find chemical combinations that promote "adequate" strength gain while the internal temperature of the mortar was below $0^{\circ} \mathrm{C}$.

One way to judge adequacy is to compare the strengths developed by antifreeze mortars cured at low temperature to those developed by normal mortar cured according to current guidelines. In practice, fresh mortar must be kept at or above $5^{\circ} \mathrm{C}$ to ensure against freezing and assure a reasonably rapid strength gain. Therefore, the strength-gain curve for control mortar cured at $5^{\circ} \mathrm{C}$ is shown in Figure 2 as the benchmark for the antifreeze mortars in this study. The curve for $20^{\circ} \mathrm{C}$ mortar is shown for comparison. Any admixture that caused mortar, cured below $0^{\circ} \mathrm{C}$, to gain strength at least as rapidly as control mortar cured at $5^{\circ} \mathrm{C}$ was deemed acceptable.

Figure 2 shows four mortars that produced at least benchmark strengths at $-10^{\circ} \mathrm{C}$. Quite a few of the chemicals produced excellent results at $-5^{\circ} \mathrm{C}$, while none passed the test at $-20^{\circ} \mathrm{C}$. The best single chemical was sodium nitrite. At a dose of $9 \%$ by weight of cement, this chemical produced strengths at $-10^{\circ} \mathrm{C}$ that not only exceeded the benchmark, they nearly equaled the strengths of control mortar cured at $20^{\circ} \mathrm{C}$ between 14 and 28 days. Thereafter, the sodium nitrite outperformed the $20^{\circ} \mathrm{C}$ control mortar. This immediately suggested that sodium nitrite, which is classified as a freezing point depressant in Table A2, could be improved further by combining it with an accelerator-something from Table A1.

Two accelerators provided that improvement. Potassium carbonate and calcium nitrite each affected sodium nitrite's performance at $-10^{\circ} \mathrm{C}$ differently. (Calcium chloride was tested in the form of a commercial deicer along with sodium nitrate as a fertilizer. They did not perform as

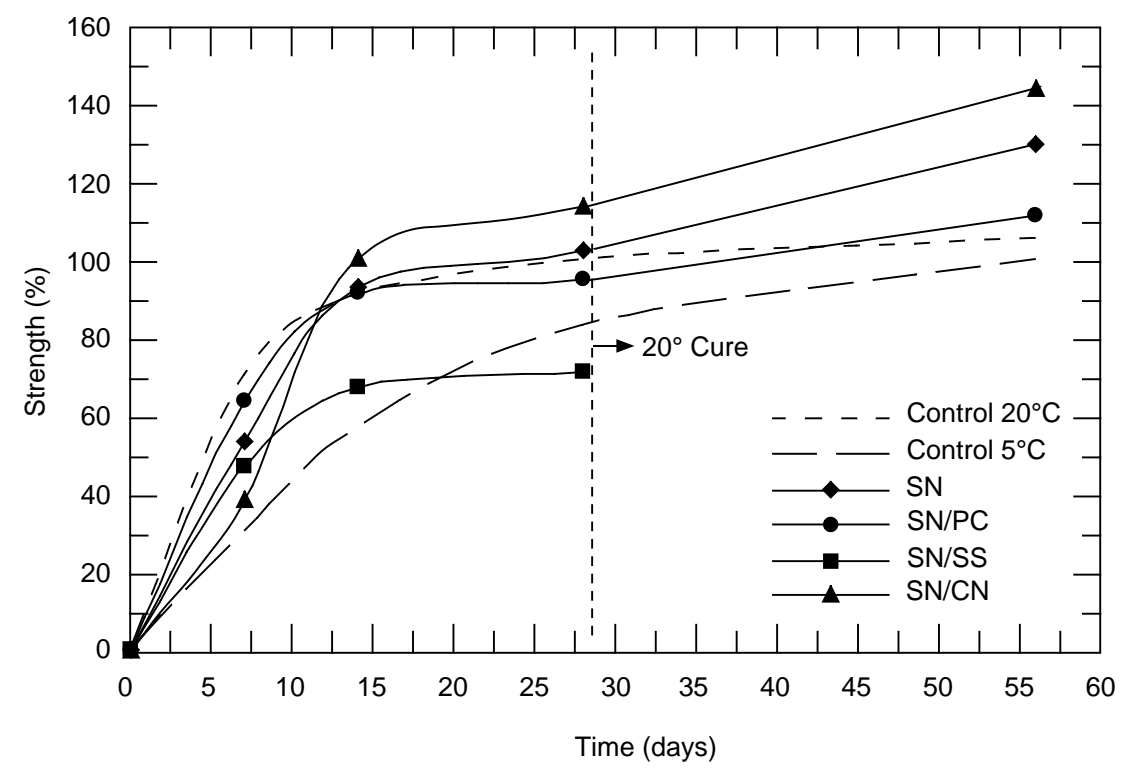

Figure 2. Best strengths at $-10^{\circ} \mathrm{C}$. 
well as expected. See Table A4 for their performance.) Calcium nitrite initially caused the early age strengths to be somewhat delayed, but they were still well above the benchmark level. The strengths beyond 14 days became significantly greater than those of the $20^{\circ} \mathrm{C}$ mortar, and greater than those of the single component sodium nitrite for that matter. This combination appears to be a long-term strength enhancer. The potassium carbonate, on the other hand, caused the mortar, at $-10^{\circ} \mathrm{C}$, to act as if it was at $20^{\circ} \mathrm{C}$ at all ages. This admixture effectively canceled the effect of cold weather. However, sodium is an alkali that can cause certain siliceous aggregates to swell destructively within concrete. More work should be done to find alternative freezing point chemicals that are benign to aggregate in the long-term or to find ways to mitigate the negative effect of added alkalis. For the short-term, these chemicals are fine as expedient admixtures.

Sodium sulfate, when combined with sodium nitrite, forms the basis of the antifreeze admixture patented by the U.S. Army in 1993. As Figure 2 shows, it produces excellent strengths up to 14 days when cured at $-10^{\circ} \mathrm{C}$ but seems to provide little benefit thereafter (it exceeds benchmark strengths at all ages when cured at $-5^{\circ} \mathrm{C}$ ). For expedient purposes, this combination of chemicals is still viable, as most severely cold weather does not last more than a few days in most parts of the world. The chemicals are readily available most anywhere, and destructive alkali reactions take 10 or more years before they become a problem.

\section{Other ways to view antifreeze admixtures}

If early age strength is not critical, another way to judge the usefulness of antifreeze admixtures is by whether they ultimately allow mortar to gain full strength even though freezing takes place during curing. The practicality of this is that a concrete structure could be cast during cold weather and then later returned to when the weather turns warm. In this light, we see in Table 3 that, even though none of the chemical dosages promoted strengths acceptable to the previous criteria while being cured at $-20^{\circ} \mathrm{C}, 12$ of them allowed essentially full recovery of strength when thawed. Thus, antifreeze admixtures can protect concrete against frost damage down to $-20^{\circ} \mathrm{C}$, perhaps lower, even though strength develops very slowly at that temperature.

Another viewpoint is to consider that we can expect normal concreting practices during the summer to result in more than a $25 \%$ loss of ultimate strength (Table 1). If one were to hold winter concrete to that same expectation, then many of the chemicals tested in this study would qualify as acceptable antifreeze admixtures.

\section{CONCLUSIONS AND RECOMMENDATIONS}

Until now, insulation, supplemental heating, and tenting have been the only ways to protect fresh concrete from freezing during cold weather. Though effective, they are costly in labor, materials, and money-and sometimes they are not

Table 3. Mortars that recovered more than $95 \%$ strength after being cured at $-20^{\circ} \mathrm{C}$ for 28 days and then at $20^{\circ} \mathrm{C}$ for an additional 28 days.

\begin{tabular}{lccc} 
Chemical & $\begin{array}{c}\text { Percent } \\
\text { by weight } \\
\text { of cement }\end{array}$ & $\begin{array}{c}\text { Freezing } \\
\text { point } \\
\left({ }^{\circ} \mathrm{C}\right)\end{array}$ & $\begin{array}{c}\text { Percent strength } \\
\text { of control mortar } \\
\text { cured for 28 days } \\
\text { at 20 } 2{ }^{\circ} \mathrm{C}\end{array}$ \\
\hline Calcium bromide & 4 & -2.9 & 105.7 \\
Calcium nitrite & 6 & -4.0 & 127.8 \\
Calcium chloride (deicer) & 6 & -5.7 & 118.8 \\
& 6 & -2.25 & 110.3 \\
Calcium magnesium acetate & 9 & -4.0 & 110.5 \\
Magnesium chloride & 8 & -8.2 & 96.4 \\
Car antifreeze-ethylene glycol & 6 & -11.5 & 96.9 \\
Calcium chloride deicer/sodium & $3 / 3$ & -6.6 & 101.0 \\
$\quad$ nitrate fertilizer & $4.5 / 1.5$ & -5.1 & 98.5 \\
Calcium chloride deicer/potash & & & 99.5 \\
$\quad$ fertilizer & $4.5 / 1.5$ & -6.6 & 98.2 \\
Fertilizer (calcium nitrate)/car & & & 96.5 \\
$\quad$ antifreeze (ethylene glycol) & $1.5 / 4.5$ & -5.2 & \\
\hline
\end{tabular}

* Tests were not conducted, or information was not available. 
Table 4. Admixtures that will produce strength at $-10^{\circ} \mathrm{C}$ at least as fast as normal concrete cured at $5^{\circ} \mathrm{C}$.

\begin{tabular}{|c|c|c|c|}
\hline Admixture & Chemicals & $\begin{array}{c}\text { Dosage } \\
\text { by wgt of cement } \\
(\%)\end{array}$ & $\begin{array}{c}\text { Water to } \\
\text { cement ratio } \\
(w / c)\end{array}$ \\
\hline 1 & $\begin{array}{l}\text { Sodium nitrite } \\
\text { Potassium carbonate }\end{array}$ & $\begin{array}{l}6.0 \\
0.06\end{array}$ & 0.45 \\
\hline 2 & $\begin{array}{l}\text { Sodium nitrite } \\
\text { Sodium sulfate }\end{array}$ & $\begin{array}{l}6.0 \\
2.0\end{array}$ & 0.48 \\
\hline 3 & $\begin{array}{l}\text { Sodium nitrite } \\
\text { Calcium nitrite }\end{array}$ & $\begin{array}{l}6.0 \\
2.0\end{array}$ & 0.45 \\
\hline 4 & Sodium nitrite & 9.0 & 0.45 \\
\hline
\end{tabular}

even available. For short-term needs, there is another way to approach winter concreting. This report shows that simply adding chemicals to the mix water will make the resulting mortar (concrete) resistant to freezing. These chemicals, called antifreeze admixtures, serve to depress the freezing point of water and to accelerate the hydration rate of cement. Their effectiveness depends on temperature, amount of chemical, and on how soon the structure is needed.

In the situation where the temperature falls below freezing but the work must still get done in a hurry, there are chemicals that will work very well. Table 4 shows four admixtures that force mortars with internal temperatures of $-10^{\circ} \mathrm{C}^{*}$ to gain strengths as if they were cured above $5^{\circ} \mathrm{C}$. Moreover, they gain more strength in the long run than control mortar cured at $20^{\circ} \mathrm{C}$ (App. A). Thus, these chemicals make cold concrete behave as if it were warm.

What happens to concrete if, soon after it is placed, its temperature dips below $-10^{\circ} \mathrm{C}$ ? All is not lost. Appendix A shows that concrete made with the Table 4 chemicals can avoid all frost damage, even when cooled to $-20^{\circ} \mathrm{C}$ for a long time. The concrete may not gain much strength at this

\footnotetext{
* It is important to know that this is a concrete temperature. Because of thermal inertia and heat generated by cement hydration, air temperatures can be much lower-further study is needed to define how low. However, until additional information becomes available, the $-10^{\circ} \mathrm{C}$ should be considered air temperature.
}

low temperature, but it recovers full strength once warm weather returns. Thus, antifreeze admixtures are sort of an insurance policy against unexpected freezing.

The above discussion assumes that concrete cast during cold weather must attain significant early or full late-age strength, or both, to be serviceable. However, attaining full strength may not be necessary. If less late-age strength can be tolerated, at least to the degree that now happens with concrete cast during hot weather, many of our everyday chemicals become potential antifreeze admixtures. Chemicals such as automobile antifreeze, alcohol, deicing salt, and common fertilizer can play an important role in protecting

Table 5. Everyday chemicals that allow concrete to gain at least $75 \% *$ strength after being at low temperature for 28 days followed by room temperature for 28 days.

\begin{tabular}{|c|c|c|c|c|c|}
\hline & \multirow[b]{2}{*}{$w / c$} & \multirow{2}{*}{$\begin{array}{c}\text { Dosage } \\
\text { by weight of } \\
\text { cement } \\
(\%)\end{array}$} & \multicolumn{3}{|c|}{$\begin{array}{l}\text { Strength }(\%) \text { relative to mortar } \\
\text { cured } 28 \text { days at } 20^{\circ} \mathrm{C}\end{array}$} \\
\hline & & & $-5^{\circ} \mathrm{C}$ & $-10^{\circ} \mathrm{C}$ & $-20^{\circ} \mathrm{C}$ \\
\hline \multicolumn{6}{|l|}{ Deicers } \\
\hline \multirow[t]{3}{*}{ Calcium chloride } & 0.41 & 3 & 121.3 & 94.9 & 80.0 \\
\hline & & 6 & 133.2 & 130.2 & 110.3 \\
\hline & & 9 & 108.3 & 100.2 & 110.5 \\
\hline \multirow[t]{3}{*}{ Potassium acetate } & 0.41 & 4 & 76.0 & 77.5 & 78.0 \\
\hline & & 6 & 115.4 & 78.6 & - \\
\hline & & 8 & 109.9 & 90.9 & - \\
\hline \multirow{3}{*}{$\begin{array}{l}\text { Calcium magnesium } \\
\text { acetate }\end{array}$} & 0.41 & 4 & 87.7 & - & - \\
\hline & & 6 & 96.2 & - & - \\
\hline & & 8 & 97.9 & 75.8 & 96.4 \\
\hline \multicolumn{6}{|l|}{ Water softener } \\
\hline \multirow{2}{*}{ Potassium Chloride } & 0.41 & 6 & 77.4 & - & - \\
\hline & & 9 & 85.3 & 79.5 & - \\
\hline \multicolumn{6}{|l|}{ Fertilizers } \\
\hline \multirow[t]{3}{*}{ Calcium nitrate } & & 3 & 98.1 & 88.1 & 76.8 \\
\hline & 0.41 & 6 & 92.2 & 98.8 & 84.3 \\
\hline & & 9 & 105.5 & 99.6 & na \\
\hline \multirow[t]{2}{*}{ Potash } & 0.41 & 6 & 90.8 & - & - \\
\hline & & 9 & 86.6 & 78.9 & - \\
\hline \multirow[t]{2}{*}{ Sodium nitrate } & 0.41 & 6 & 109.4 & - & - \\
\hline & & 9 & 108.8 & 103.1 & 一 \\
\hline \multicolumn{6}{|l|}{ Car antifreezes } \\
\hline \multirow[t]{3}{*}{ Ethylene glycol } & 0.38 & 3 & 87.6 & 80.2 & - \\
\hline & 0.35 & 6 & 119.1 & 103.6 & 101.0 \\
\hline & 0.32 & 9 & 95.8 & 93.0 & 88.6 \\
\hline \multirow[t]{3}{*}{ Propylene glycol } & 0.38 & 3 & 90.8 & 83.8 & 81.9 \\
\hline & 0.35 & 6 & 86.2 & - & - \\
\hline & 0.32 & 9 & 88.1 & 80.5 & 一 \\
\hline \multicolumn{6}{|l|}{ Alcohols } \\
\hline \multirow[t]{3}{*}{ Methyl (wood) } & 0.38 & 3 & 75.7 & - & - \\
\hline & 0.35 & 6 & 96.9 & 88.4 & - \\
\hline & 0.32 & 9 & 79.3 & 83.7 & - \\
\hline Ethyl (grain) & 0.37 & 4.1 & 83.6 & - & - \\
\hline Iso-propyl & 0.35 & 6 & 90.0 & - & - \\
\hline
\end{tabular}

* The $75 \%$ requirement reflects what happens to concrete strength when it is cured at $50^{\circ} \mathrm{C}$. In the table, blank spaces indicate that the chemical did not produce enough strength; na means that tests were not conducted at that condition. 
concrete from freezing when other chemicals are not available. Although concrete made with these chemicals may not develop much strength early on, Table 5 shows that the concrete recovers at least $75 \%$ of its potential strength once thawed. In the situation where concrete can be placed and returned to when the weather turns warm, these chemicals should not be overlooked.

The chemicals shown in Table 4 are used in a wide variety of manufacturing processes, from pharmaceuticals to food additives and, as such, are readily available most anywhere. Using them or the ones in Tables 3 and 5 in concrete is quite simple. Weigh enough water for one batch of concrete, dissolve the appropriate chemical or chemicals in that water, one chemical at a time, and then follow standard concrete mixing procedures after that. Once the concrete is placed, consolidated, and finished, cover it with a sheet of plastic for 3-7 days to minimize evaporation. Because of differences in cements and how they react with various chemicals, the field results could vary from those of this report. Thus, concrete mixes made with any chemical shown in this report should be tested before use. It is recommended that trial batches of the concrete to be used in the field be made with the chemicals and evaluated for strength gain at the temperatures expected in the field. Until further work is done, it is recommended that a minimum of $363 \mathrm{~kg}$ of Type I portland cement be used per cubic meter of concrete, and that the $\mathrm{w} / \mathrm{c}$ ratio should be no higher than those used in this report. The aggregates should be ice-free.

\section{WHAT WE STILL DON'T KNOW}

Additional work should be done to make optimal the combinations of chemicals used in this study to improve concrete performance at lower temperatures. The work should include not only reformulating these chemicals and testing them for the best dosages, but it should include a search for other chemicals that can make concrete set up fast. Specific attention should be given to combining the Table 5 chemicals with others to enhance their performance in concrete.

An effort should also be made to determine the minimum chemical dosage required for protection against frost damage. Such a dosage would not be expected to promote much strength at low temperatures, but it might become routinely used in all winter concreting as a vaccine against unexpected cold. The findings in this study suggest that even small dosages of some chemicals protect concrete from damage when the weather gets bitterly cold. Normal concrete is damaged as soon as the temperature drops a fraction of a degree below freezing.

For long-term applications, antifreeze admixtures should be studied for their effect on the freeze-thaw resistance of concrete. Preliminary data at CRREL and elsewhere suggest that the addition of certain chemicals into concrete can significantly increase its freeze-thaw resistance. One explanation for this improvement is that much of the antifreeze probably remains in the pore water solution; it may not combine with the hydration products. This, in turn, depresses the freezing point of the concrete so that it experiences fewer freeze-thaw cycles than would normal concrete exposed to the outside environment. Another possible mechanism is that the dissolved particles somehow prevent the mixing water from fully expanding, even when fully frozen. Laboratory measurements of freezing mortars show that mortars containing antifreeze produce less expansive pressure than do normal mortars. Less expansion translates into less damage. Thus, antifreeze admixtures might have the residual benefit of making concrete more durable.

Data also suggest that antifreeze chemicals can increase the salt-scaling resistance of concrete pavements, bridges, and other structures subject to deicing salts. Preliminary studies conducted elsewhere show that concrete made with an antifreeze admixture is more resistant to freeze-thaw cycling in salt water than is normal concrete. Osmosis is one explanation for salt scaling. Deicing salts create highly concentrated solutions on bridge decks, for example. To equalize these concentration differences, water may try to flow out of the concrete, creating considerable pressures and causing the concrete surface to spall. Finding the right chemical dosage to reduce this pressure may translate into huge savings in reduced repair bills.

Current guidance forbids placement of fresh concrete onto a frozen substrate to prevent a bottom layer of concrete from freezing. Preliminary studies (Korhonen et al. 1997a) showed that concrete can be placed on very cold crushed stone without problem. Guidance on when normal concrete can be placed on frozen substrates needs to be developed, both to avoid any freezing and to determine how to thicken the concrete should freezing be unavoidable. Work should also be done define the effect of various substrates on antifreeze concrete.

Finally, the relationship between the tempera- 
ture of the concrete and that of the air is not well understood. It is a function of the heat evolved during curing, the air temperature, geometry, and other variables. Work needs to be done to enable low-temperature concrete to be mathematically modeled. Much of the modeling already done for normal concrete at temperatures above $5^{\circ} \mathrm{C}$ can be used in this endeavor. Knowing how to predict concrete performance is vital to efficient and safe winter construction.

\section{LITERATURE CITED}

ASTM (1987) C305-82, Standard practice for mechanical mixing of hydraulic cement pastes and mortars of plastic consistency. Annual Book of ASTM Standards, Section 4, Vol. 04.01. Philadelphia, Pennsylvania: American Society for Testing and Materials.

ASTM (1993) C1231-93, Standard practice for use of unbonded caps in determination of compressive strength of hardened concrete cylinders. Annual Book of ASTM Standards, Section 4, Vol.
04.02. Philadelphia, Pennsylvania: American Society for Testing and Materials.

ASTM (1997) C39-96, Standard Practice for compressive strength of cylindrical concrete specimens. Annual Book of ASTM Standards, Section 4, Vol. 04.02. Philadelphia, Pennsylvania: American Society for Testing and Materials.

Korhonen, C.J., and J.W. Brook (1996) Freezing temperature protection admixture for portland cement concrete. USA Cold Regions Research and Engineering Laboratory, Special Report 9628.

Korhonen, C.J., B. Charest, and K. Romisch (1997a) Developing new low-temperature admixtures for concrete. USA Cold Regions Research and Engineering Laboratory, Special Report 97-9. Korhonen, C.J., E.R. Cortez, T.A. Durning, and A.A. Jeknavorian (1997b) Antifreeze admixtures for concrete. USA Cold Regions Research and Engineering Laboratory, Special Report 97-26.

U.S. Army (1998) Concrete and masonry. FM 5428. Headquarters, Department of the Army, Washington, D.C. 


\section{APPENDIX A: PERFORMANCE DATA}

The following four tables present performance data from mortar made with the chemicals evaluated in this testing phase. They present the effect of the chemicals on the freezing point of the mixing water in the mortar and on the strength gain of the mortar cured at $20,-5,-10$, and $-20^{\circ} \mathrm{C}$. Freezing points were determined by embedding thermocouples into cylinders of fresh mortar placed into a $-20^{\circ} \mathrm{C}$ room. From the resulting cooling curve, the freezing point was identified as the point where the slope of the curve changed. For pure water, the slope of the cooling curve becomes zero until all of the water turns into ice. Since mix water is a solution, its solute concentration increases as pure ice freezes out, which progressively lowers the freezing point. Thus, it is that the cooling curve slope only changes and does not become zero as it does with water. The dosages at which the chemicals were evaluated are presented as a percentage of the weight of cement in the mortar and as molality-the number of solute particles added per kilogram of mix water. Because the formulation of all chemicals was not known, the number of solute particles added to the mix water could not be provided in all cases. The strengths are given as percentages of the 28-day strength of control mortar cured at $20^{\circ} \mathrm{C}$. The majority of the strengths are given for $7,14,28$, and 56 days at $20,-5,-10$, and $-20^{\circ} \mathrm{C}$. Where applicable, the mortars are cured for the first 28 days at the temperature indicated above each column, then an additional 28 days at room temperature.

Table A1 presents the results from chemicals that had a propensity to cause increased mortar strengths at 7 days compared to that of control mortar (see Table 1 in the body of the report for comparison) when cured at $20^{\circ} \mathrm{C}$. Table A2 shows the results from chemicals that had little tendency to promote early strength or that may have caused delayed strength, but that provided freezing point depression merely by being in the mortar. Table A3 lists the results from chemicals that are liquid regardless of whether they act as accelerators or freezing point depressants. The Table A4 chemicals were combined in an attempt to create an admixture providing both freezing-point depression and accelerated strength gain of mortar at temperatures below $0^{\circ} \mathrm{C}$. Time did not allow for the optimization of chemical combinations. This should be a topic of future study. 


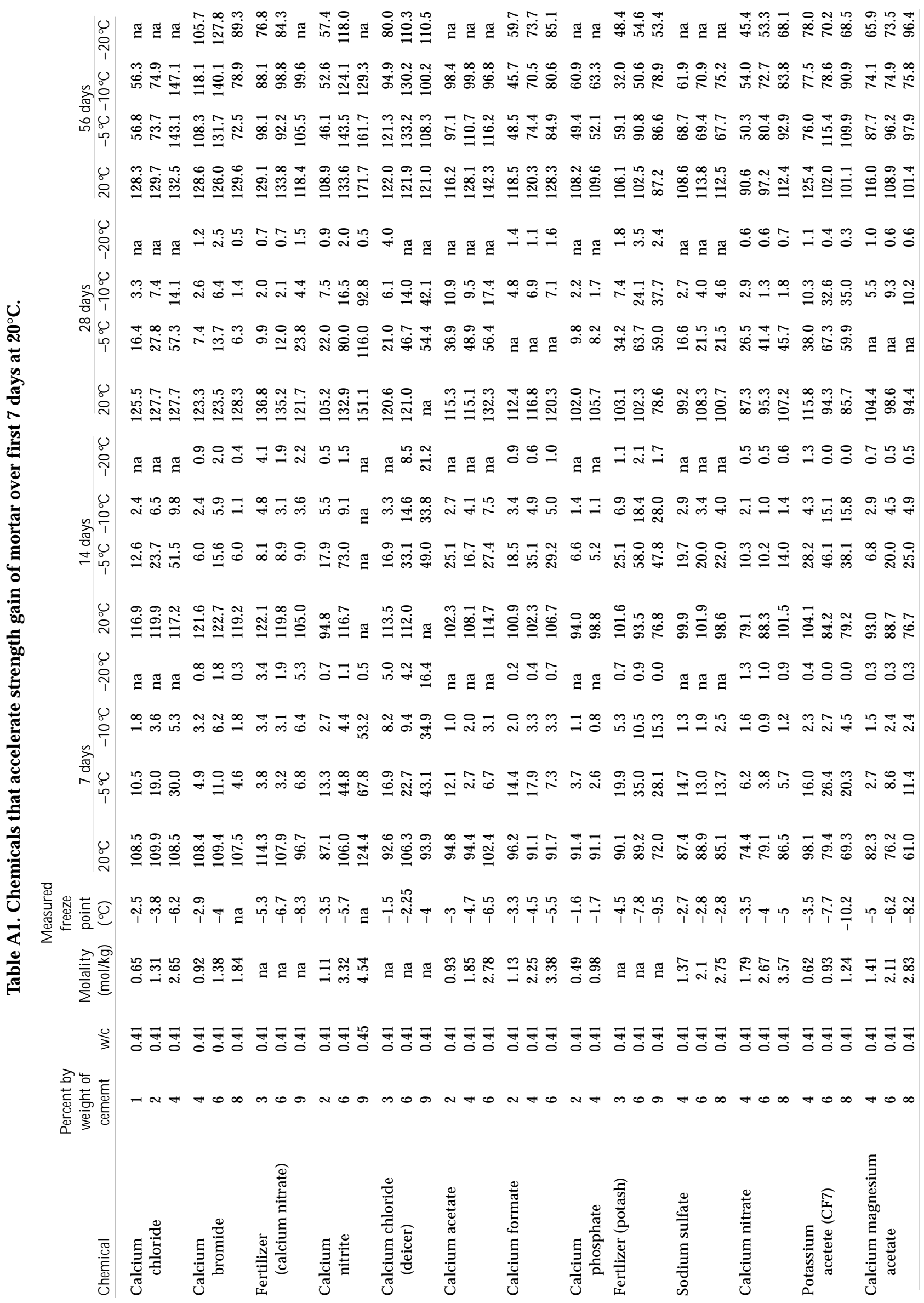




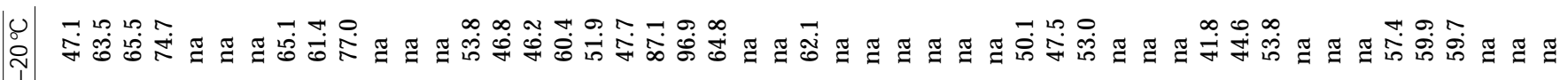

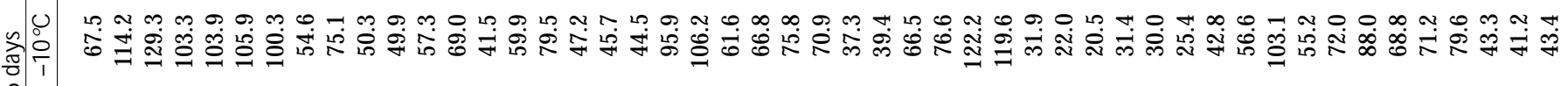

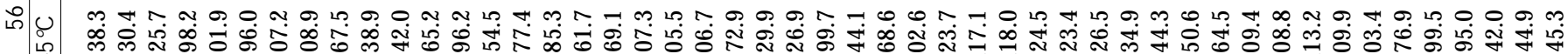

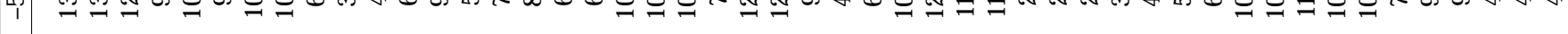
管

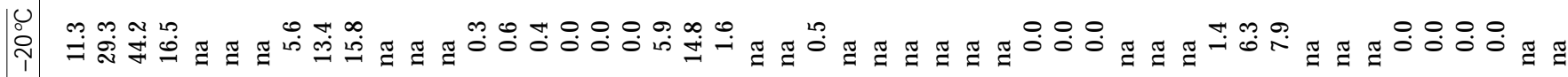

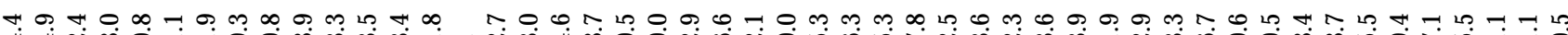
i \ п

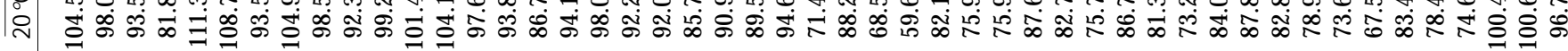

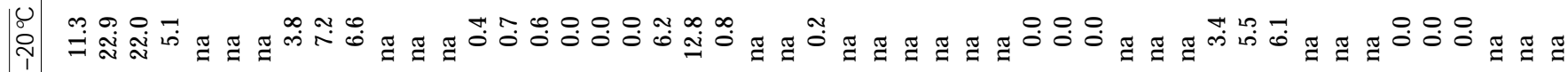

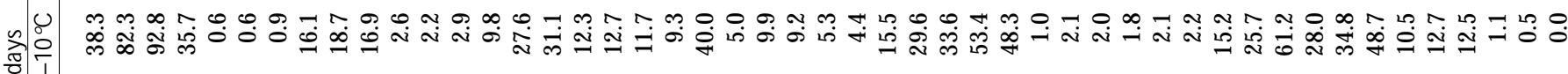

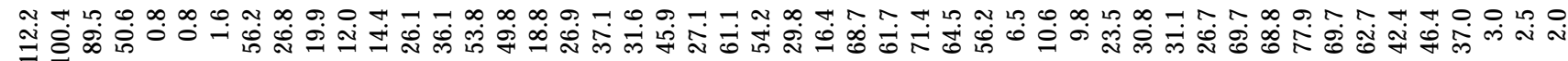
○

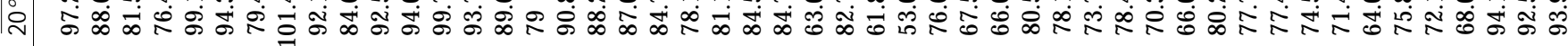

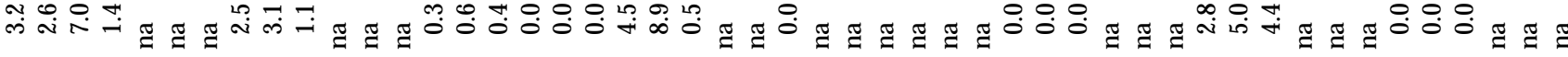

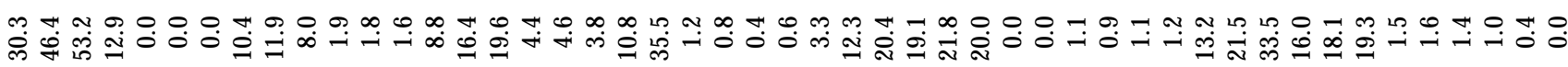
\#

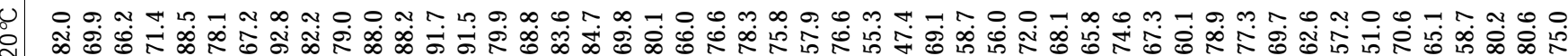
空.亭 0

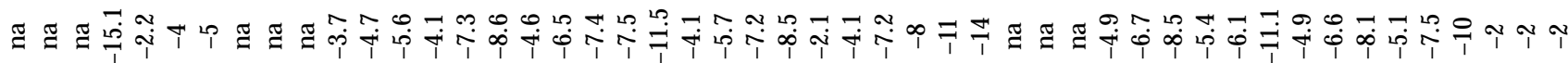

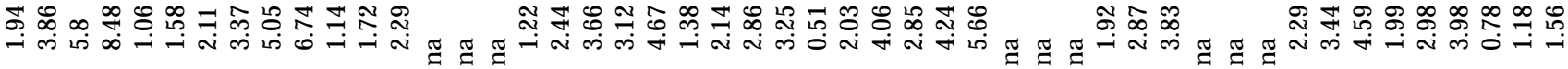

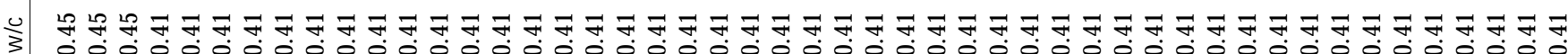

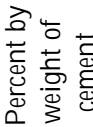
mod 


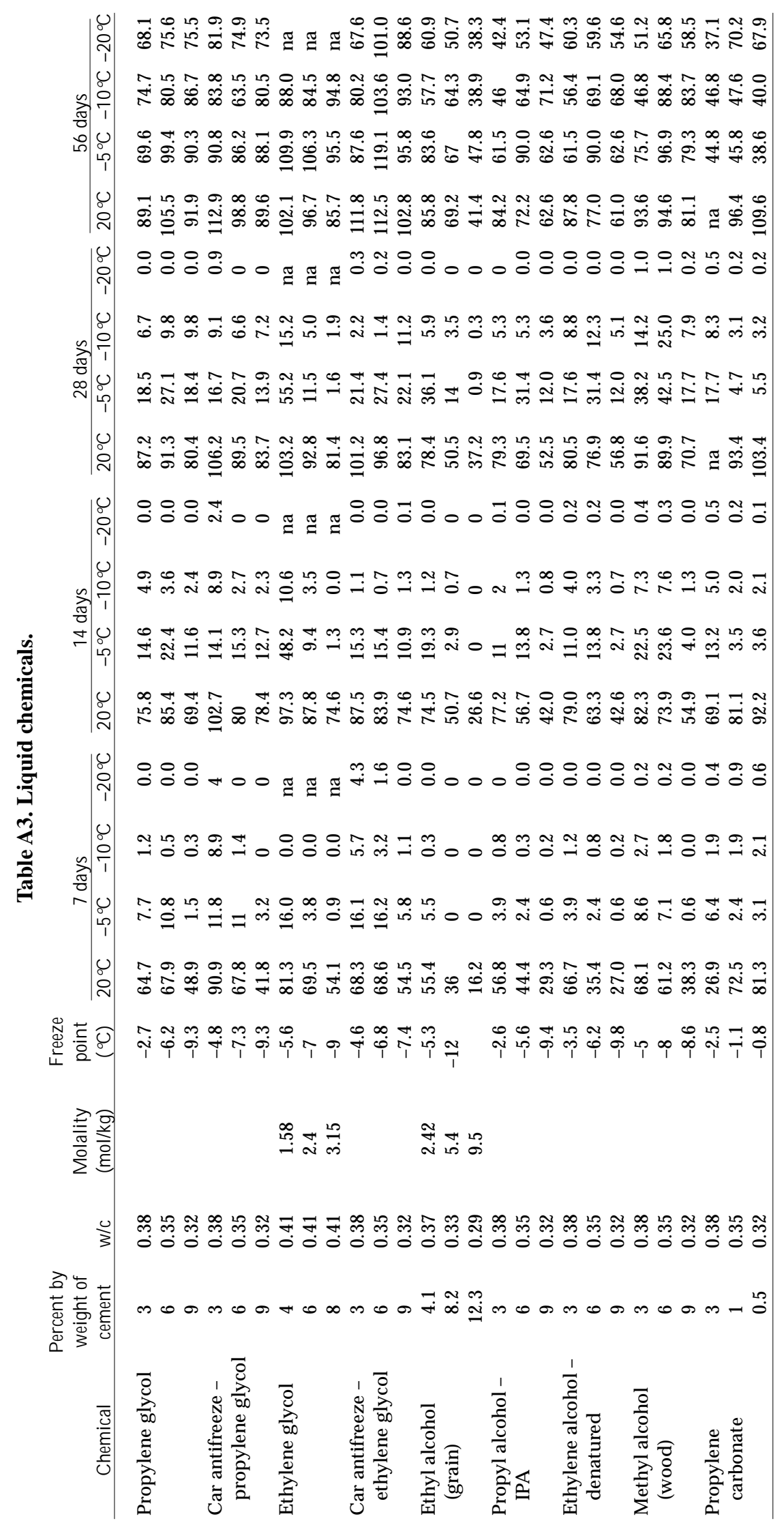




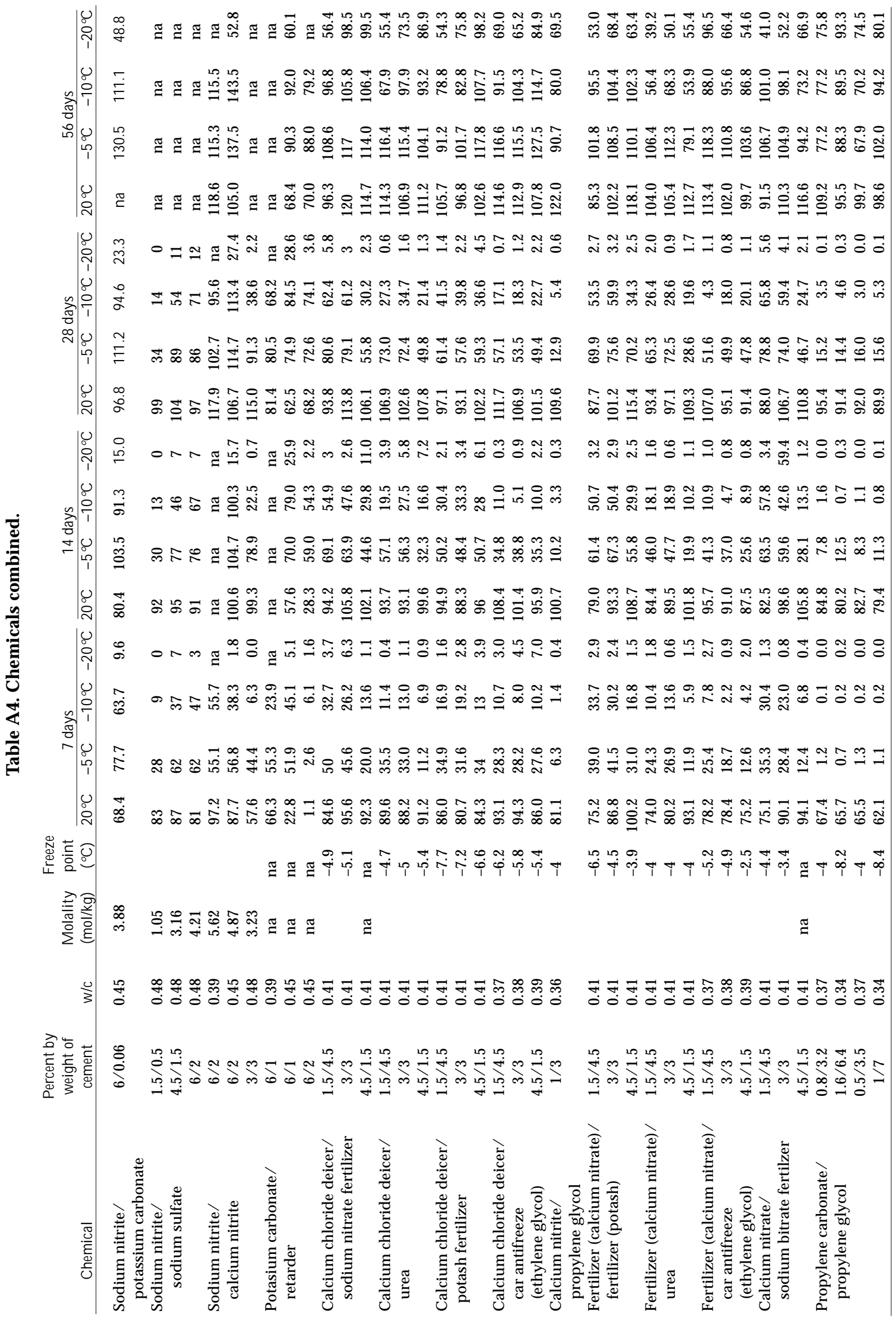




\section{REPORT DOCUMENTATION PAGE}

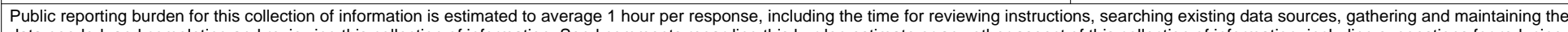

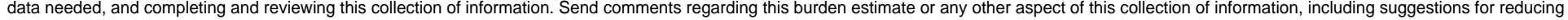

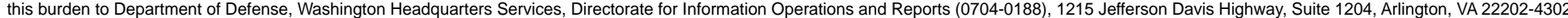

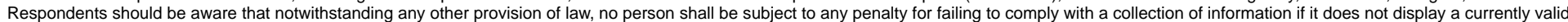
OMB control number. PLEASE DO NOT RETURN YOUR FORM TO THE ABOVE ADDRESS.

\begin{tabular}{|l|l|l|l}
\hline 1. REPORT DATE $(D D-M M-Y Y)$ & 2. REPORT TYPE & 3. DATES COVERED (FrOm - To)
\end{tabular}

November 1999

4. TITLE AND SUBTITLE

5a. CONTRACT NUMBER

Expedient Low-Temperature Concrete Admixtures for the Army

5b. GRANT NUMBER

5c. PROGRAM ELEMENT NUMBER

4A762784AT42

6. AUTHOR(S)

5d. PROJECT NUMBER

5e. TASK NUMBER

Charles J. Korhonen

5f. WORK UNIT NUMBER

AT42-TO-011

7. PERFORMING ORGANIZATION NAME(S) AND ADDRESS(ES)

8. PERFORMING ORGANIZATION REPORT NUMBER

U.S. Army Engineer Research and Development Center

Cold Regions Research and Engineering Laboratory

72 Lyme Road

Hanover, New Hampshire 03755-1290

Special Report 99-17

9. SPONSORING/MONITORING AGENCY NAME(S) AND ADDRESS(ES)

10. SPONSOR / MONITOR'S ACRONYM(S)

Office of the Chief of Engineers

Washington, D.C. 20314

11. SPONSOR / MONITOR'S REPORT

$\operatorname{NUMBER}(S)$

\section{DISTRIBUTION / AVAILABILITY STATEMENT}

Approved for public release; distribution is unlimited.

Available from NTIS, Springfield, Virginia 22161.

13. SUPPLEMENTARY NOTES

\section{ABSTRACT}

Over 50 chemical combinations were studied for their effect on the strength gain of mortar when it is below freezing. The chemicals studied were limited to those that are readily available most anywhere, but that are not marketed as admixtures for concrete. Four admixtures were developed from these chemicals that allowed mortar to gain full strength at $-10^{\circ} \mathrm{C}$ as rapidly as normal mortar cured at temperatures between 5 and $10^{\circ} \mathrm{C}$. A host of other chemicals allowed mortar to recover full strength when cooled to the point that cement hydration ceased or that allowed mortar to continually gain modest strength while at low temperature with only minimal loss of ultimate strength. Guidance is provided for expedient field use-for concrete not expected to last more than 5 years.

\section{SUBJECT TERMS}

Antifreeze mixture Expedient construction

Cold-weather concrete Low-temperature construction

\begin{tabular}{|c|c|c|c|c|c|}
\hline \multicolumn{3}{|c|}{ 16. SECURITY CLASSIFICATION OF: } & \multirow{2}{*}{$\begin{array}{l}\text { 17. LIMITATION OF } \\
\text { OF ABSTRACT }\end{array}$} & \multirow{2}{*}{$\begin{array}{l}\text { 18. NUMBER } \\
\text { OF PAGES }\end{array}$} & \multirow{2}{*}{\begin{tabular}{|l|} 
19a. NAME OF RESPONSIBLE PERSON \\
19b. TELEPHONE NUMBER (include area code)
\end{tabular}} \\
\hline a. REPORT & b. ABSTRACT & c. THIS PAGE & & & \\
\hline Unclassified & Unclassified & Unclassified & UL & 20 & \\
\hline
\end{tabular}

